\title{
Prevalence of Balantidium coli in cattle and cattle breeders in some regions of Baghdad in Iraq
}

\author{
Hussin AG ${ }^{1}$, FR Al-Samarai ${ }^{2 *}$ \\ ${ }^{1}$ Al-Elam Sector for Primary Health Care, Alkarkh Health Directorate Baghdad, Ministry of Health, Iraq; \\ ${ }^{2}$ Department of Veterinary Public Health, Faculty of Veterinary Medicine, University of Baghdad, Iraq
}

\begin{abstract}
A study was carried out to determine the prevalence of Balantidium coli infection in cattle and their breeders and related risk factors including the gender, age and region. A total of 200 cattle faecal samples were collected from different ages, sexes and regions of Baghdad (Hor-rageb, Abu Ghraib, ALJaderiya, AL-Makaseb, AL-Dowanem and AL-Hamdaniaa) and 88 breeder faecal samples from ALMakaseb, AL-Dowanem and AL-Hamdaniaa during the period from November 2014 to May 2015. The results showed that the prevalence of Balantidium coli were $29.50 \%$ and $9.09 \%$ in cattle and their breeders, respectively. The association between infection and all studied factors was not significant except between infection and regions in cattle which were significant $(P<0.01)$. Based on the results of this research, it can be concluded that cattle are highly susceptible to balantidiasis irrespective of sex and age.
\end{abstract}

Key words: cattle, cattle breeders, prevalence, Balantidium coli

Bangladesh Animal Husbandry Association. All rights reserved.

Bang. J. Anim. Sci. 2016. 45 (2): 30-34

\section{Introduction}

In cattle, the disease problems especially caused by protozoa lead to loss of productivity in terms of mortality, reduced milk, and meat (Kaltungo and Musa, 2013). Therefore, it is necessary to identify the type of protozoa causing infection in the cattle to prevent, control and adopt the effective treatment. No doubt, the topic becomes more importance when the effect of protozoa is not limited to only cattle but extend to include humans also. Among the protozoan diseases, Balantidiasis caused by B.coli considered as one of an important disease that could infect animals and humans (Levine, 1995; Schuster and Ramirez-Avila, 2008). Several reports confirmed that, $B$. coil could be emerge as a significant pathogen that is able to cause disease in horses (Headley et al., 2008), buffaloes (Tarrar et al., 2008), cattle (Randhawa et al., 2010) and camels (Abubakr et al., 2000; AL-Tayib, 2014; Cox, 2005). However, the Balantidiasis did not represent a serious problem in Japan according to the conclusion demonstrated by Nakauchi (1999) who found a low rate of infections in 56 mammalian species.

*Corresponding author: firas_rashad@yahoo.com
Moreover, Thompson and Smith (2011) stated that, although, Balantidium is known to cause infections in humans and is considered to be zoonotic but its role in zoonotic transmission is likely to be minimal. The same situation exists in Arabian countries, although, Balantidiasis is a zoonotic disease, a few researchers gave it their attention. This could be attributed to two reasons: Firstly, this disease can be found wherever pigs are found and in Islamic countries like Iraq, pigs are not breeding because their religious beliefs prohibit consumption of pork. Secondly, Balantidium could infect pigs and other mammals along with humans, but its effect on the gastrointestinal tract usually not serious. It can thrive there in balance with its host without causing dysenteric symptoms, such as severe diarrhoea and bloody stools. However, the problem could arise with the existence of malnutrition, alcoholism, or a compromised immune system virus [HIV]/AIDS, etc.). Those act to upset the balance in favor of the ciliate, leading to disease (Anargyrou et al., 2003; Vasilakopolou et al., 2003; Ferry et al., 2004).

On the other hand, there are other reasons can tip the balance in favor of estimate the prevalence of balantidiasis according to Schuster and Ramirez-Avila, (2008), there are some fears 
of balantidiosis that can be expressed as the probability of increasing the prevalence of balantidiosis due to the warming of the earth's surface that could provide appropriate environment, particularly in the temperate areas of the world, for survival of trophozoite and cystic stages of Balantidium. Moreover, SolaymaniMohammadiet al., (2004) reported that wild boars were a reservoir for Balantidium in rural Western Iran, and it could be the source of infection in livestock and humans. The wild boars are existed in Iraq (Ministry of Environment, 2010). However, its role in infection was not studied.

As water is the vehicle for most cases of balantidiosis, disease could represent a problem in developing countries, as the opportunity of water sources to contaminate with porcine or human faeces (Schuster and Ramirez-Avila, 2008). The information available is scanty about the prevalence of Balantidium coli in cattle and their breeders. Hence, this study was aimed to investigate their prevalence of Balantidium coli along with their associated risk factors.

\section{Materials and Methods}

A total of 200 cattle faecal samples were collected from different ages, sexes and regions of Baghdad (Hor-rageb, Abu Ghraib, AL-Jaderiya, AL-Makaseb, AL-Dowanem and AL-Hamdaniaa) and 88 breeder faecal samples from AL-Makaseb, AL-Dowanem and AL-Hamdaniaa. All samples collected during the period from November 2014 to May 2015. The faecal samples were collected directly from the rectum, in a clean plastic containers $(100 \mathrm{ml}$ size) and were tightly closed and given sequential numbers. All information for the animal and breeder included age, sex and the name of region were recorded on a special form bearing the number of the sample. Then the samples were transported in refrigerated bag to the zoonotic unite at the College of Veterinary Medicine in Baghdad University. The samples were examined at the laboratory of the Department of Parasitology in the same College by direct wet mount, Lugol's iodine staining technique and modified Ziehle-Nelseen staining to identify the Balantidiumcolias described by Soulsby, (1982) and Levine, (1995).

\section{Results and Discussion}

Results revealed that the prevalence of Balantidium coli in cattle from different regions of Baghdad, Iraq was $29.50 \%$ (Table 1 ). The present estimation is higher than $27.5 \%$ in India (Niphadkar and Raote, 1994), 25.29\% in Bangladesh (Rahman and Samad, 2010), 25\% in Pakistan (Bilal, 2006), 17.19\% in Indonesia (Wisesa et al., 2015) and 6.6\% in Kenya (Kanyari et al., 2010) and lower than $45.45 \%$ in India (Palanivel et al. 2005) and 45.03\% in Bangladesh (Roy et al., 2011).

Table 1. Infection rate of $B$. coli according to gender in cattle

\begin{tabular}{llc}
\hline Gender & $\begin{array}{l}\text { Total } \\
\text { (number) }\end{array}$ & $\begin{array}{l}\text { Percentage of positive } \\
\text { numbers }\end{array}$ \\
\hline Male & 65 & 32.30 \\
Female & 135 & 28.14 \\
Chi-square & & 0.37 \\
P value & & 0.55 \\
Total & 200 & 29.50 \\
\hline
\end{tabular}

The variation in estimations of prevalence could be attributed to several factors such as breed, sample size, selection of samples, the technique of sample examination, agro-ecological, geoclimatic conditions, management and nutrition (Hussin, 2015). Table 1 showed the infection rates in male and female cattle were $32.30 \%$ and $28.14 \%$, respectively. The association between gender and infection was not significant. The result is consistent with the result obtained by Kanyari et al., (2010) and Singh et al., (2012) in cattle which supported to the earlier finding of Azhar et al., (2002) who reported both male and female buffalo have the same chance of being infected with the Fasciola sp. However, the result of this study contrasted with the result obtained by Wisesa et al., (2015) who found that the infection rate of balantidiasis in cattle was significantly $(p<0.05)$ higher in male $(23.20 \%)$ than female $(13.72 \%)$. On the other hand, opposite results were found by Bachal et al., (2002) who reported the infection rate of Balantidium coli in the female buffalo (48.30\%) was higher than the male buffalo $(45.12 \%)$. Roy et al., (2011) found the similar result and reported a higher prevalence of balantidiasis in 


\section{Balantidium coli in cattle and cattle breeders}

female buffalo (47.32\%) compared to male buffalo $(38.46 \%)$.

Table 2. Infection rate of $B$. coli according to age in cattle

\begin{tabular}{llc}
\hline Age/year & Total (number) & $\begin{array}{c}\text { Percentage of positive } \\
\text { numbers }\end{array}$ \\
\hline$<1$ & 58 & 29.31 \\
$1-<3$ & 49 & 26.53 \\
$3-<6$ & 47 & 27.65 \\
$6 \leq$ & 46 & 34.78 \\
Chi-square & & 0.90 \\
$P$ & & 0.82 \\
\hline
\end{tabular}

The inconsistencies in the results could be belonged to the differences in the physiological condition of cattle (pregnancy, lactation and parturition and lower feed supplements for production) which may cast a shadow on infection rate and lead to decreasing the resistance of animal (Roy et al., 2011).

Table 3. Infection rate of $B$. coli according to regions in cattle

\begin{tabular}{llc}
\hline Regions & $\begin{array}{l}\text { Total } \\
\text { (number) }\end{array}$ & $\begin{array}{l}\text { Percentage of positive } \\
\text { numbers }\end{array}$ \\
\hline Hor-Rageb & 31 & 0 \\
Abu-Ghraib & 34 & 20.58 \\
AL-Jaderiya & 26 & 0 \\
AL-Makaseb & 38 & 34.21 \\
AL-Dowanem & 37 & 56.75 \\
AL-Hamdaniaa & 34 & 52.94 \\
Chi sq & & 47.75 \\
P & & $<0.01$ \\
\hline
\end{tabular}

The levels of prolactin and progesterone hormones affect the female. Higher levels of those hormones may fall female more susceptible to any infection (Lloyd, 1983). Meanwhile, male cattle are also susceptible to stress and this will decrease its resistance to infection (Mamun et al., 2011).Concerning the difference among age groups, results showed that the differences were not significant (Table 2). These results supported the previous results obtained by Kanyari et al., (2010) and Wisesa et al., (2015). Meanwhile, our results disagreed with the results of Roy et al., (2011) who reported that age was significantly influenced the infection rate of balantidiasis. The effect of regions on the infection rate of balantidiasis of cattle in the present study was significant $(\mathrm{P}<0.01)$ while no infection of Balantidium was found in two regions (Hor-ragab and Al-Jaderia). Similar results reported by
Kanyari et al., (2010) and Wisesa et al., (2015). The differences could be attributed to variation in herd size, status of animal, types of food and water, food supply systems, hygienic conditions, the level of veterinary care, and drugs or vaccinations (Hussin, 2015).

Table 4: Infection rate of $B$. coli according to gender in cattle breeders

\begin{tabular}{llc}
\hline Gender & $\begin{array}{l}\text { Total } \\
\text { (number) }\end{array}$ & $\begin{array}{l}\text { Percentage of positive } \\
\text { numbers }\end{array}$ \\
\hline Male & 33 & 12.12 \\
Female & 55 & 7.2 \\
Chi-square & & 0.58 \\
P & & 0.44 \\
Total & 88 & 9.09 \\
\hline
\end{tabular}

Results shown in Table (4) showed that the prevalence of Balantidium coli in breeders $(9.09 \%)$ was higher. $1.4 \%$ in Thailand (Chavalittamrong and Jirapinyo, 1984), 2.4\% in children of India (Kaur et al., 2002) and $6.67 \%$ in Bangladesh (Al-Hasan et al., 2015). Although there are several factors could be responsible for these differences but contact with animals could play a big role for these variations.

The infection rates in male and female breeders were $12.12 \%$ and $7.20 \%$, respectively. However, the association between gender and infection was not significant. The present finding disagreed with results obtained by Biu et al. (2008) who reported that prevalence of balantidiasis was higher in male $(11.5 \%)$ than female $(3.4 \%)$. The non-significant effect of gender on the rate of infection is anticipated because, in rural regions, both males and females are contacted with cattle and exposed to same pathogenic agents (Hussin, 2015).

Table 5: Infection rate of $B$. coli according to age in breeders

\begin{tabular}{llc}
\hline Age/year & Total (number) & $\begin{array}{l}\text { Percentage of positive } \\
\text { numbers }\end{array}$ \\
\hline$<10$ & 38 & 13.15 \\
$10-<30$ & 27 & 7.40 \\
$30 \leq$ & 23 & 4.34 \\
Chi-square & & 1.47 \\
P & & 0.47 \\
\hline
\end{tabular}

Despite the infection rate showed a decreasing trend with advanced age but the association between age category and infection was not significant (Table 5). These results disagreed with 
results reported by Biu et al. (2008) and AlHasan et al., (2015) who confirmed the significant effect of age on infection rate of Balantidium coli.

Table 6. Infection rate of $B$. coli according to age in cattle breeders

\begin{tabular}{lcc}
\hline Age/year & $\begin{array}{l}\text { Total } \\
\text { (number) }\end{array}$ & $\begin{array}{l}\text { Percentage of } \\
\text { positive numbers }\end{array}$ \\
\hline AL-Makaseb & 27 & 11.11 \\
AL-Dowanem & 32 & 12.50 \\
AL-Hamdaniaa & 29 & 3.44 \\
Chi-square & & 1.70 \\
P & & 0.42 \\
\hline
\end{tabular}

Results also revealed that the association between infection and regions was not significant (Table 6). Based on the results of this research, it can be concluded that the high prevalence of Balantidium coli infection in cattle (29.50\%) indicated that cattle are highly susceptible to

\section{References}

Abubakr M., Nayel MN., Fadlalla M., Abdelrahman AO., Abuobeida S., Elgabara YM. (2000). Prevalence of gastrointestinal parasites in young camels in Bahrain.Revue d'élevageet de médecinevétérinaire des pays tropicaux.53: 267-271.

Al-Hasan A., Ali A., Al-Hasan A., Rakib FK., Alam MA., Mondal MM. (2015). Prevalence of Balantidium coli infection in man in Mymensingh, Bangladesh. International Journal of Natural and Social Sciences. 2:33-36.

AL-Tayib O. (2014). Zoonotic balantidiasis in camel from Saudi Arabia. Scholars Academic Journal of Biosciences. 2(7): 445-447.

Anargyrou KGL., Petrikkos MTE., Suller A., Skiada MR., Siakantaris RT., Osuntoyinbo G., Pangalis C., and Vaiopoulos G. (2003). Pulmonary Balantidium coli infection in a leukemic patient. American Journal of Hematology.73: 180-183.

Azhar M., Chaudhry SH., Tanveer A., Haji AH. (2002). Epidemiology of fasciolosis in buffaloes under different managemental conditions. Veterinarski Arhiv. 72 (4):221-228.

Bachal B., Sharif P., Rahamatullah R.,Aijaz HS. (2002). Prevalence of gastro-intestinal helminths in Buffalo calves. Journal of Biological Sciences. 2(1): 43-45.

Bilal CQ., Khan MS., Avais M., Ijaz M., Khan JA. (2009). Prevalence and chemotherapy of Balantidium coli in cattle in the River Ravi region balantidiasis irrespective of gender and age. On the other hand, the prevalence of Balantidium coli in breeders is also high $(9.09 \%)$, that will double the adverse effect of infection because it is known, that the presence of pathogenic bacteria (e.g., Salmonella) in the intestine can worsen an infection by invading colonic lesions caused by Balantidium coli (Levine, 1961; Skotarczak, 1997a, 1997b; Sestak et al., 2003). The results also reflect the poor sanitary condition, drinking of contaminated water and lack of knowledge about health and hygiene.

\section{Conflict of interest statement}

We declare that we have no conflict of interest.

\section{Acknowledgements}

The work was financially supported by the Faculty of Veterinary Medicine, University of Baghdad, Iraq.

Lahore (Pakistan). Veterinary Parasitology. 163:1-2

Bilal CHQ. (2006). Prevalence and chemotherapy of Balantidium coli in cattle around River Ravi bank Lahore MPhil Thesis. Dept of Clinical Medicine \& Surgery University of Veterinary and Animal Sciences Lahore Pakistan. pp31Burgess Publishing Co Minneapolis, MN.

Biu AA., Dauda M. (2008). Prevalence study on enteric protozoans responsible for a copromicroscopical investigation in Sardinia.Parassitologia. 48 (14): 313-314.

Chavalittamrong B., Jirapinyo P. (1984). Intestinal parasites in pediatric patients with diarrhael diseases in Bangkok. Southeast Asian Journal of Tropical Medicine and Public Health. 15: 385388

Cox FE. (2005). Human balantidiasis in Iran: are camels' reservoir hosts TredParasitol 21: 553

Ferry TD., Bouhour F., De Monbrison F., Laurent H., Domouchel-Champagne S., Picot MA., and Granier P. (2004). Severe peritonitis due to Balantidium coli acquired in France. European Journal of Clinical Microbiology \& Infectious Diseases.23:393-395.

Headley SA., Kummala E., Sukura A. (2008). Balantidium coli infection in a Finnish horse.Veterinary Parasitology.158: 129-132.

Hussin AG. (2015). Evaluation of different diagnostic methods for zoonotic intestinal protozoz in cattle 
camels and their breeders A thesis Faculty of Veterinary Medicine University of Baghdad Iraq.

Kaltungo BY., Musa IW. (2013). A Review of Some Protozoan Parasites Causing Infertility in Farm Animals.ISRN Tropical Medicine. Article ID 782609: http://dx.doi.org/10.1155/2013/782609.

Kanyari PWN., Kagira JM., Mhoma JRL. (2010). Prevalence of endoparasites in cattle within urban and peri-urban areas of Lake Victoria Basin Kenya with special reference to zoonotic potential. Scientia Parasitologica. 11(4):171178.

Kaur R., Rawat D., Kakkar M., Uppal B., Sharma VK. (2002). Intestinal parasites in children with diarrhea in Delhi India. Southeast Asian Journal of Tropical Medicine and Public Health. 33(4): 725-729

Levine ND. (1961). Protozoan parasites of Domestic Animals and of Man. Burgess Publishing Co., Minneapolis. Pp. 133.

Levine ND. (1995).Veterinary ProtozoologyAmes: Iowa State University Press.

Lloyd S. (1983). Effect of pregnancy and lactation up on infection. Veterinary Immunology Immunopathology. 4: 153-176.

Mamun MAA., Begum N., Mondal MMH. (2011). A coprological survey of gastro-intestinal parasites of water buffaloes (Bubalus bubalis) in Kurigram district of Bangladesh. Journal of Bangladesh Agricultural University. 9(1):103-109.

Ministry of Environment. (2010). Iraqi fourth national report to the convention on biological diversity Iraq.

Nakauchi K. (1999). The pre valence of Balantidium coli infection in fifty-six mammalian species. The Journal of Veterinary Medical Science. 61:6365.

Palanivel KM., Thangathurai R., Nedunchellian S. (2005). Epizootiology of Balantidium coli infection in ruminants. Indian Veterinary Journal. 82(6): 682-683.

Rahman MM., Samad MA. (2010). Prevalence of subclinical gastro-intestinal parasitosis and their effects on milk production with therapeutic management in Red Chittagong cattle. Bangladesh Journal of Veterinary Medicine. 8: 11-16.
Randhawa S., Singla LD., Randhawa C. (2010). Chronic cattle diarrhea due to Balantidium coli infection-a clinical report. Journal of Veterinary Parasitology. 24:197-198.

Schuster FL., Ramirez-Avila L. (2008).Current world status of Balantidium coli. Clinical Microbiology Reviews. 21(4):626-638.

Sestak KCK., Merritt J.,Borda E., Saylor SR.,Schwamberger F., Cogswell ES., Didier PJ., Didier G.,Plauche RP., Bohn PP., Aye P., Alexa RL.,Lackner AA. (2003). Infectious agent and immune response characteristics of chronic enterocolitis in captive rhesus macaques. Infection and Immunity. 71:4079-4086.

Singh NK., Singh H., Haque M., Rath SS. (2012). Prevalence of parasitic infections in buffaloes in and around Ludhiana District Punjab India: A preliminary study. Journal of Parasite Diseases. 36(2): 256-259.

Skotarczak B. (1997a). Bacterial-flora in acute and symptom-free balantidiosis. Acta Parasitology. 42:230-233.

Skotarczak B., (1997b). Ultrastructural and cytochemical identification of peroxisomes in Balantidium coli Ciliophora. Folia Biologica. 45:117-120.

Solaymani-Mohammadi S., Rezaian M., Hooshyar H., Mowlavi GR., Babaei Z., Anwar MA.(2004). Intestinal protozoa in wild boars (Sus scrofa) in Western Iran. Journal of wildlife diseases. 40: 801-803.

Tarrar MA., Khan MS., Pervez K., Ashraf K., Khan JA., Rehman ZU. (2008). Detection and chemotherapy of Balantidium coli in buffaloes around Lahoure Pakistan. Pakistan Journal of Agricultural Science. 5(2):163-166.

Thompson RCA., Smith A. (2011). Zoonotic enteric protozoa. Veterinary Parasitology.182: 70- 78.

Vasilakopolou AK., Dimarongona A., Samakovli K., Avlami A. (2003). Balantidium coli pneumonia in an immunocompromised patient. Scandinavian Journal of Infectious Diseases. 35:144-146.

Wisesa IBGR., Siswanto FM., Putra TA., Oka IBM., Suratma NA. (2015). Prevalence of Balantidium $s p$. in Bali cattle at different areas of Bali. International Journal of Agriculture Forestry and Plantation.1:49-53. 